\title{
Pemanfaatan Media Berbasis Teknologi dalam Pembelajaran
}

[Artikel: Media Pembelajaran STKIP Nurul Huda 2018]

Thoha Firdaus

(Kandidat Doktor UPI)

PROGRAM STUDI PENDIDIKAN FISIKA

SEKOLAH TINGGI KEGURUAN DAN ILMU PENDIDIKAN (STKIP) NURUL HUDA OKU TIMUR

2018 
Pemanfaatan Media Berbasis Teknologi dalam Pembelajaran | Thoha Firdaus

\section{Pengertian}

Pengertian media secara terminologi cukup beragam, sesuai sudut pandang para pakar media pendidikan. Kata media pembelajaran berasal dari bahasa latin medius yang berarti tengah, perantara atau pengantar. Sadiman dalam Musfiqon (2012: 26) mengatakan media adalah perantara atau pengantar pesan pengirim ke penerima pesan. Dalam bahasa arab, media juga berarti perantara (wasail) atau pengantar pesan dari pengirim kepada penerima pesan. Gerlach \& Ely dalam Arifin (2008: 23) mengatakan bahwa media apabila dipahami secara garis besar adalah manusia, materi, atau kejadian yang membangun kondisi yang membuat siswa mampu memperoleh pengetahuan, keterampilan, atau sikap. Dalam pengertian ini guru, buku teks, dan lingkungan sekolah merupakan media. Secara lebih khusus, pengertian media dalam proses belajar mengajar cenderung diartikan alat-alat grafis, photografis, atau elektronis untuk menangkap, memproses, dan menyusun kembali informasi visual dan verbal.

Berdasarkan definisi tersebut, dapat dikatakan bahwa proses pembelajaran merupakan proses komunikasi. Jadi, media pembelajaran adalah segala sesuatu yang dapat digunakan untuk menyalurkan pesan (bahan pembelajaran), sehingga dapat merangsang perhatian, minat, pikiran, dan perasaan siswa dalam kegiatan belajar untuk mencapai tujuan belajar.

\section{Klasifikasi}

Dari segi perkembangan teknologi, media pembelajaran dapat dikelompokkan menjadi dua kategori luas, yaitu pilihan media tradisional dan pilihan media teknologi mutakhir (Seels \& Glasgow dalam Arsyad, 2002:33). Lebih lanjut dijelaskan bahwa pilihan media tradisional dapat dibedakan menjadi:

1. Visual diam yang diproyeksikan, misal proyeksi opaque (tak tembus pandang), proyeksi overhead, slides, dan filmstrips,

2. Visual yang tidak diproyeksikan, misal gambar, poster, foto, charts, grafik, diagram, pemaran, papan info,

3. Penyajian multimedia, misal slide plus suara (tape), multi-image,

4. Visual dinamis yang diproyeksikan, misal film, televisi, video,

5. Cetak, misal buku teks, modul, teks terprogram, workbook, majalah ilmiah/berkala, lembaran lepas (hand-out),

6. Permainan, misal teka-teki, simulasi, permainan papan, dan

7. Realia, misal model, specimen (contoh), manipulatif (peta, boneka). Sedangkan pilihan media teknologi mutakhir dibedakan menjadi (1) media berbasis telekomunikasi, misal teleconference, kuliah jarak jauh, dan (2) media berbasis 
mikroprosesor, misal computer-assistted instruction, permainan komputer, sistem tutor intelejen, interaktif, hypermedia, dan compact (video) disc.

\section{Ciri-ciri media pembelajaran}

Arsyad (2006: 24) mengemukakan tiga ciri media yang merupakan petunjuk mengapa media digunakan dan apa saja yang dapat dilakukan oleh media yang mungkin guru tidak mampu (kurang efisien) dalam melakukannya, yaitu:

1) Ciri fiksatif (fikxative property)

Menggambarkan kemampuan media merekam, menyimpan, melestarikan, dan merekonstruksi suatu peristiwa atau objek. Suatu peristiwa atau objek dapat diurut dan disusun kembali dengan media seperti fotografi, video tape, audio tape, disket komputer dan film. Dengan ini, media memungkinkan suatu rekaman atau objek yang terjadi pada suatu waktu tertentu ditransportasikan tanpa mengenal waktu. Ciri ini amat penting bagi guru karena kejadian-kejadian atau objek yang telah direkam atau disimpan dengan format media yang dapat digunakan setiap saat.

2) Ciri manipulatif (manipulative property)

Transformasi suatu kejadian atau objek dimungkinkan karena media memiliki ciri manipulatif. Kejadian yang memakan waktu berhari-hari dapat disajikan kepada siswa dalam waktu dua atau tiga menit dengan teknik pengambilan gambar time-lapse recording. Misalnya, bagaimana proses larva menjadi kepompong kemudian menjadi kupu-kupu dapat dipercepat dengan teknik rekaman fotografi tersebut. Kemampuan media dari ciri manipulatif memerlukan perhatian sungguh-sungguh karena apabila terjadi kesalahan dalam pengaturan kembali urutan kejadian atau pemotongan bagian-bagian yang salah, maka akan terjadi pula kesalahan penafsiran yang tentu saja akan membingungkan dan bahkan menyulitkan siswa.

3) Ciri distributif (distributive property)

Ciri distributif dari media memungkinkan suatu objek atau kejadian ditransportasikan melalui ruang secara bersamaan. Kejadian tersebut disajikan pada sebagian besar siswa dengan stimulus pengalaman yang relatif sama mengenai kejadian itu. Informasi bisa direkam serta dapat direproduksi beberapa kali dan dapat digunakan secara bersamaan atau berulang-ulang diberbagai tempat.

Ketiga ciri ini merupakan karakteristik media yang dapat digunakan dalam pembelajaran. Terkadang guru harus menyampaikan sesuatu yang telah terjadi pada masa lampau, rung dan waktu yagn terbatas, serta materi ayng disajikan sangat abstrak. Dengan mempertibangkan hal ketiga ini guru dapat memilih, menciptakan, dan menggunakan media. 


\section{Kedudukan media dalam pembelajaran}

Pembelajaran merupakan sistem yang terdiri dari berbagai komponen. Dalam pembelajaran terdapat komponen tujuan, komponen materi atau bahan, komponen strategi, komponen alat dan media, serta komponen evaluasi. Dari sini tampak bahwa media merupakan salah satu komponen dalam proses pembelajaran, sehingga kedudukannya tidak hanya sekedar sebagai alat bantu mengajar, tetapi sebagai bagian integral dalam proses pembelajaran. Kedudukan media sangat penting, sebab dapat menunjang keberhasilan pembelajaran. Bahkan bila dikaji lebih jauh, media tidak hanya sebagai penyalur pesan yang harus dikendalikan sepenuhnya oleh sumber berupa orang, tetapi dapat juga menggatikan sebagian tugas guru dalam penyajian materi pelajaran.

\section{Tujuan Media Pembelajaran}

Penggunaan media pengajaran sangat diperlukan dalam kaitannya dengan peningkatan mutu pendidikan khususnya dalam pembelajaran membaca puisi. Menurut Achsin (1986:17-18) menyatakan bahwa tujuan penggunaan media pengajaran adalah:

1. Agar proses belajar mengajar yang sedang berlangsung dapat berjalan dengan tepat guna dan berdaya guna,

2. Untuk mempermudah bagi guru/pendidik daiam menyampaikan informasi materi kepada anak didik,

3. Untuk mempermudah bagi anak didik dalam menyerap atau menerima serta memahami materi yang telah disampaikan oleh guru/pendidik,

4. Untuk dapat mendorong keinginan anak didik untuk mengetahui lebih banyak dan mendalam tentang materi atau pesan yang disampaikan oleh guru/pendidik,

5. Untuk menghindarkan salah pengertian atau salah paham antara anak didik yang satu dengan yang lain terhadap materi atau pesan yang disampaikan oleh guru/pendidik.

Sedangkan Sudjana, dkk. (2002:2) menyatakan tentang tujuan pemanfaatan media adalah:

1. Pengajaran akan lebih menarik perhatian siswa sehingga dapat menimbulkan motivasi,

2. Bahan pelajaran akan lebih jelas maknanya sehingga dapat lebih dipahami,

3. Metode mengajar akan lebih bervariasi, dan 
4. Siswa akan lebih banyak melakukan kegiatan belajar. Jadi dapat disimpulkan bahwa tujuan penggunaan media adalah (1) efektivitas dan efisiensi dalam kegiatan belajar mengajar, (2) meningkatkan motivasi belajar siswa, (3) variasi metode pembelajaran, dan (4) peningkatan aktivasi siswa dalam kegiatan belajar mengajar.

\section{Fungsi media pembelajaran}

Pada dasarnya media hanya berfungsi sebagai alat bantu visual dalam kegiatan pembelajaran, yaitu berupa sarana yang dapat memberikan pengalaman visual kepada siswa antara lain untuk mendorong motivasi belajar, memperjelas dan mempermudah konsep yang kompleks dan anstrak manjadi lebih sederhana, konkrit, serta mudah difahami. Dengan demikian media dapat berfungsi untuk mempertinggi daya serap belajar siswa terhadap materi pembelajaran (Miarso dalam Musfiqon, 2012: 32).

Arsyad (2006: 15) mengemukakan bahwa pemakaian media pembelajaran dalam proses belajar mengajar dapat membangkitkan keinginan dan minat baru, membangkitkan motivasi dan merangsang kegiatan belajar, dan bahkan membawa pengaruh-pengaruh psikologi terhadap siswa. Penggunaan media pembelajaran pada tahap orentasi pembelajaran akan sangat membantu keefektifan proses pembelajaran dan penyampaian pesan dan isi pembelajaran pada saat itu.

Menurut Benni Agus Pribadi dalam Musfiqon (2012: 33), media pembelajaran berfungsi sebagai berikut:

1) Membantu memudahkan belajar bagi siswa dan juga mempermudah proses pembelajaran bagi guru.

2) Memberikan pengalaman lebih nyata (abstrak menjadi konkrit).

3) Menarik perhatian siswa lebih besar (jalanya pembelajaran tidak membosankan).

4) Semua indra siswa dapat diaktifkan.

5) Dapat membangkitkan dunia teori dengan realitanya.

Fungsi media pembelajaran, dapat juga dilihat dari segi perkembangan media itu sendiri, yaitu:

1) Pada mulanya berfungsi sebagai alat bantu mengajar.

2) Dengan masuknya audio-visual intruction, media berfungsi memerikan pengalaman konkrit kepada siswa.

3) Munculnya teori komunikasi menyebabkan media mempunyai fungsi sebagai alat penyalur pesan/informasi belajar. 
4) Adanya penggunaan pendekatan sistem dalam pembelajaran media berfungsi sebagai bagian integral dalam program pembelajaran.

5) Akhirnya, media bukan saja sekedar berfungsi sebagai peraga bagi guru, tetapi pembawa informasi/pesan pembelajaran yang dibutuhkan (Soeharto dalam Musfiqon, 2012: 34)

\section{Perangkat media pembelajaran}

Perangkat media dapat terdiri atas: material, equipment, hardware, dan software. Istilah material berkaitan erat dengan istilah equipment dan istilah hardware berhubungan dengan istilah software. Material (bahan media) adalah sesuatu yang dapat dipakai untuk menyimpan pesan yang akan disampaikan kepada auidien dengan menggunakan peralatan tertentu atau wujud bendanya sendiri, seperti transparansi untuk perangkat overhead, film, filmstrip, dan film slide, gambar, grafik, dan bahan cetak. Sedangkan equipment (peralatan) ialah sesuatu yang dipakai untuk memindahkan atau menyampaikan sesuatu yang disimpan oleh material kepada audien, misalnya proyektor film slide, video tape recorder, papan tempel, papan flanel, dan sebagainya.

Istilah hardware dan software tidak hanya dipakai dalam dunia komputer, tetapi juga untuk semua jenis media pembelajaran. Contoh, isi pesan yang disimpan dalam transparansi OHP, kaset audio, kaset video, film slide. Software adalah isi pesan yang disimpan dalam material, sedangkan hardware adalah peralatan yang digunakan untuk menyampaikan pesan yang telah dituangkan ke dalam material untuk dikirim kepada audien. Contoh, proyektor overhead, proyektor film, video tape recorder, proyektor slide, proyektor filmstrip.

\section{Manfaat}

Secara umum manfaat penggunaan media pengajaran dalam kegiatan belajar mengajar, yaitu:

1. Media pengajaran dapat menarik dan memperbesar perhatian anak didik terhadap materi pengajaran yang disajikan,

2. Media pengajaran dapat mengatasi perbedaan pengalaman belajar anak didik berdasarkan latar belakang sosil ekonomi,

3. Media pengajaran dapat membantu anak didik dalam memberikan pengalaman belajar yang sulit diperoleh dengan cara lain,

4. Media pengajaran dapat membantu perkembangan pikiran anak didik secara teratur tentang hal yang mereka alami dalam kegiatan belajar mengajar mereka, misainya menyaksikan pemutaran film tentang suatu kejadian atau peristiwa. rangkaian dan urutan kejadian yang mereka saksikan dan pemutaran film tadi akan dapat mereka pelajari secara teratur dan berkesinambungan, 
5. Media pengajaran dapat menumbuhkan kemampuan anak didik untuk berusaha mempelajari sendiri berdasarkan pengalaman dan kenyataan,

6. Media pengajaran dapat mengurangi adanya verbalisme dalain suatu proses (dalam bentuk kata-kata tertulis atau lisan belaka) (Latuheru, 1988:23-24).

Sedangkan menurut Sadiman, dkk. (2002:16), media pengajaran dapat mengatasi keterbatasan ruang, waktu, dan daya indera, misalnya (1) obyek yang terlalu besar bisa digantikan dengan realita, gambar, film, atau model, (2) obyek yang kecil bisa dibantu dengan menggunakan proyektor, gambar, (3) gerak yang terlalu cepat dapat dibantu dengan timelapse atau high-speed photography, (4) kejadian atau peristiwa di masa lampau dapat ditampilkan dengan pemutaran film, video, foto, maupun VCD, (5) objek yang terlalu kompleks (misalnya mesin-mesin) dapat disajikan dengan model, diagram, dan lain-lain, dan (6) konsep yang terlalu luas (misalnya gunung berapi, gempa bumi, iklim, dan lain-lain) dapat divisualisasikan dalam bentuk film, gambar, dan lain-lain.

Pemanfaatan media pembelajaran dalam proses belajar mengajar perlu direncanakan dan dirancang secara sistematik agar media pembelajaran itu efektif untuk digunakan dalam proses belajar mengajar. Ada beberapa pola pemanfaatan media pembelajaran, yaitu (1) pemanfaatan media dalam situasi kelas atau di dalam kelas, yaitu media pembelajaran dimanfaatkan untuk menunjang tercapainya tujuan tertentu dan pemanfaatannya dipadukan dengan proses belajar mengajar dalam situasi kelas, (2) pemanfaatan media di luar situasi kelas atau di luar kelas, meliputi (a) pemanfaatan secara bebas yaitu media yang digunakan tidak diharuskan kepada pemakai tertentu dan tidak ada kontrol dan pengawasan dad pembuat atau pengelola media, serta pemakai tidak dikelola dengan prosedur dan pola tertentu, dan (b) pemanfaatan secara terkontrol yaitu media itu digunakan dalam serangkaian kegiatan yang diatur secara sistematik untuk mencapai tujuan pembelajaran yang telah ditentukan untuk dipakai oleh sasaran pemakai (populasi target) tertentu dengan mengikuti pola dan prosedur pembelajaran tertentu hingga mereka dapat mencapai tujuan pembelajaran tersebut, (3) pemanfaatan media secara perorangan, kelompok atau massal, meliputi (a) pemanfaatan media secara perorangan, yaitu penggunaan media oleh seorang saja (sendirian saja), dan (b) pemanfaatan media secara kelompok, baik kelompok kecil ( $2-8$ orang) maupun kelompok besar (9-40 orang), (4) media dapat juga digunakan secara massal, artinya media dapat digunakan oleh orang yang jumlahnya puluhan, ratusan bahkan ribuan secara bersama-sama. 
Berdasarkan pendapat tersebut di atas, dapat dikatakan bahwa seorang guru dalam memanfaatkan suatu media untuk digunakan dalarn proses belajar mengajar harus memperhatikan beberapa hal, yaitu (1) tujuan pembelajaran yang akan dicapai, (2) isi materi pelajaran, (3) strategi belajar mengajar yang digunakan, (4) karakteristik siswa yang belajar. Karakteristik siswa yang belajar yang dimaksud adalah tingkat pengetahuan siswa terhadap media yang digunakan, bahasa siswa, artinya isi pesan yang disampaikan melalui media harus disesuaikan dengan tingkat kemampuan berbahasa atau kosakata yang dimiliki siswa sehingga memudahkan siswa dalam memahami isi materi yang disampaikan melalui media. Selain itu, penting juga untuk memperhatikan jumlah siswa. Artinya media yang digunakan hendaknya disesuaikan dengan jumlah siswa yang belajar.

\section{Referensi}

Arifin, J. 2012. Eksplorasi Tabel Data dan Formula MS Excel 2007-2010. Jakarta: PT Elex Media Komputindo

Musfiqon. 2012. Pengembangan Media \&amp; Sumber Pembelajaran. Jakarta: PT: Prestasi Pustakaraya.

Arsyad, Azhar. 2006. Media Pembelajaran. Jakarta: PT. Raja Grafindo Kusuma, W. 2011. Pengembangan Media Pembelajaran Berbasis Komputer dengan Aplikasi Program Camtasia pada Mata Pelajaran Fisika SMA Kelas 1 Untuk Topik Gerak Melingkar. Yogyakarta: Faklultas Keguruan dan Ilmu Pendidikan Universitas Ahmad D ahlan. 